\title{
Lucio's Phenomenon. Case study of an exceptional response to treatment exclusively with multibacillary multidrug therapy*
}

\author{
Fenômeno de Lúcio. Relato de um caso exuberante com excelente resposta ao \\ tratamento com Poliquimioterapia Multibacilar
}

\author{
Amanda Braga Peixoto ${ }^{1}$ \\ Fabiano Roberto Pereira de Carvalho Leal $^{2}$ \\ Nilton Carlos dos Santos Rodrigues ${ }^{4}$
}

\author{
Poliana Santin Portela ${ }^{1}$ \\ Arles Martins Brotas ${ }^{3}$
}

DOI: $h$ ttp://dx.doi.org/10.1590/abd1806-4841.20132398

\begin{abstract}
Lucio's phenomenon represents a serious cutaneous necrotizing reaction, which can occur with Lucio's leprosy and also in other forms of lepromatous leprosy. The authors discuss the case of a 63-year-old male patient presenting with ulcers and necrotic cutaneous lesions on the limbs, torso and face, associated with recurring sinusitis, hoarseness and a weight loss of 25 kilos over the last year. Bacilloscopy of intradermal scrapings showed a bacilloscopic index of 5 and the histopathological findings were compatible with the diagnosis of Lucio's phenomenon. The chosen treatment was exclusively multibacillary multidrug therapy, resulting in important dermatological improvement after one month of therapy. The authors present an impressive case of Lucio's phenomenon with an exceptional response to treatment exclusively with multibacillary multidrug therapy.
\end{abstract}

Keywords: Drug therapy, combination; Leprosy, lepromatous; Treatment outcome

Resumo: O fenômeno de Lúcio representa uma reação cutânea necrosante grave que pode ocorrer na hanseníase de Lúcio e em outras formas de hanseníase virchowiana. Os autores relatam o caso de um paciente masculino de 63 anos de idade apresentando há um ano lesões ulceronecróticas nos membros, lóbulos auriculares e tronco, associadas a sinusite de repetição, rouquidão e perda ponderal de $25 \mathrm{~kg}$. A baciloscopia de raspado intradérmico mostrou índice baciloscópico de 5 e o exame histopatologico foi compatível com fenômeno de Lúcio. O tratamento instituído foi exclusivamente com poliquimioterapia multibacilar (PQT-MB), havendo melhora importante do quadro cutâneo após um mês de tratamento. Os autores apresentam um caso exuberante de fenômeno de Lúcio que obteve excelente resposta ao tratamento somente com PQT-MB.

Palavras-chave: Hanseníase Virchowiana; Quimioterapia combinada; Resultado de tratamento

\section{INTRODUCTION}

Hansen's disease or leprosy is a chronic infectious illness that is considered endemic in Brazil. It is caused by the Mycobacterium leprae (M leprae), which is transmitted via respiratory route, after a lengthy and intimate contact with an untreated bacilliferous patient. ${ }^{1}$ Depending on the patient's immune system, the infection may evolve to cure or to one of its clinical presentations: indeterminate, tuberculoid, borderline or lepromatous. ${ }^{2}$ The wide clinical spec- trum of leprosy is linked to variations on the patient's immune responses to the infection. Therefore, lepromatous leprosy occurs in subjects that present with a deficiency in the cellular immunity response to $\mathrm{M}$ leprae, while tuberculoid leprosy is linked to a higher resistance to the bacillus. Intermediate leprosy presentations, including borderline tuberculoid, borderlineborderline and borderline lepromatous are unstable forms of the disease. Leprous reactions are acute and

\footnotetext{
Received on 03.01.2013.

Approved by the Advisory Board and accepted for publication on 21.03.2013.

* Work performed at Marcílio Dias Naval Hospital (HNMD) - Rio de Janeiro (RJ), Brazil.

Conflict of interest: None

Financial funding: None

MD - Post-graduation in Dermatology at Marcílio Dias Naval Hospital (HNMD) - Rio de Janeiro (RJ), Brazil.

Assistant professor at Rio de Janeiro Pontifical Catholic University (PUC-RJ) and at Professor Rubem David Azulay Institute dermatology clinics - Preceptor at Santa Casa de Misericórdia do Rio de Janeiro Hospital and at Marcílio Dias Naval Hospital (HNMD) - Rio de Janeiro (RJ), Brazil.

MD, PhD in dermatology at Rio de Janeiro State University (UERJ) - Preceptor at Marcílio Dias Naval Hospital dermatology clinics (HNMD) - Rio de Janeiro (RJ), Brazil.

Military Commander at Marcílio Dias Naval Hospital dermatology clinics (HNMD) - Rio de Janeiro (RJ), Brazil.

(C2013 by Anais Brasileiros de Dermatologia
} 
frequent manifestations that disrupt the indolent chronic course of the disease and reflect the immunological instability of the patient. According to the clinical and histopathological manifestations, reaction cases may be classified as: type 1 or reversal reaction, and type 2 including erythema nodosum leprosum, erythema polymorphe and Lucio's phenomenon. Some authors recognize the latter condition as a reaction type 3 .

\section{CASE REPORT}

A sixty-three year old male patient informed the gradual appearance of painless hemorrhagic blisters on limbs, earlobes and torso one year ago. These lesions later regressed spontaneously, leaving only atrophic scars on their previous sites. He also reported several bouts of recurring sinusitis, hoarseness and progressive worsening of the cutaneous lesions. This patient had a previous history of Chronic Obstructive Pulmonary Disease (COPD), hyperuricemia and high blood pressure treated with an irregular use of nifedipine. He denied smoking, drinking or the use of illicit drugs and he also had no family history of dermatologic diseases similar to his own. During admission, the patient status was cachectic; he was dehydrated, asthenic, dyspneic and afebrile (Figure 1). Physical examination showed an infiltrated face, with madarosis, besides ulceronecrotic geometrically shaped lesions affecting the limbs, torso and face. In some segments, these lesions would converge; leaving large denuded areas (Figure 2). Neurologic examination demonstrated bilaterally thickened fibular nerves, which were painless to palpation. Laboratory exams revealed anemia (hemoglobin: $9.5 \mathrm{~g} / \mathrm{dL}$; hematocrit: 29.9\%; MVC: $76.5 \mathrm{fL})$, bandemia (10\%), hypoproteinemia $(5.1 \mathrm{~g} / \mathrm{dL})$, and elevated levels of $\mathrm{C}$ reactive protein $(\mathrm{CRP})$ and erythrocyte sedimentation rate (ESR) $(27.4 \mathrm{mg} / \mathrm{L}$ and $82 \mathrm{~mm} / \mathrm{h}$ respectively); Anti-HIV, VDRL, Antinuclear Factor (ANF), AntiDNA e anti-cardiolipin antibodies (ACA) were all negative. Skin smear bacilloscopy demonstrated a bacilloscopic level of 5 (i.e. the presence of an average of 100 to 1,000 bacilli per examined field). The results of a biopsy on a forearm opened lesion showed an ulcerated epidermis, accompanied by a dense histiocitary infiltrate with peri-adnexal and interstitial distribution; the presence of vascular fibrinoid necrosis with neutrophilic infiltrate and associated edema; also the presence of numerous granular bacilli by the FiteFaraco stain, often arranged in a cluster-like formation (Figure 3). The histopathological findings were compatible with the diagnosis of Virchowian hanseniasis, exhibiting Lucio's phenomenon reaction. Radiographies of the hands showed bone resorption on the right fifth digit; rhinoscopy visualized a nasal septal perforation; a decrease of diameter in the glottic region was detected by the videolaringoscopy; and the Mitsuda test was negative. The treatment of choice was exclusively with multibacillary multidrug therapy leading to a marked improvement in the cutaneous signs and symptoms after one month of use (Figure 4).

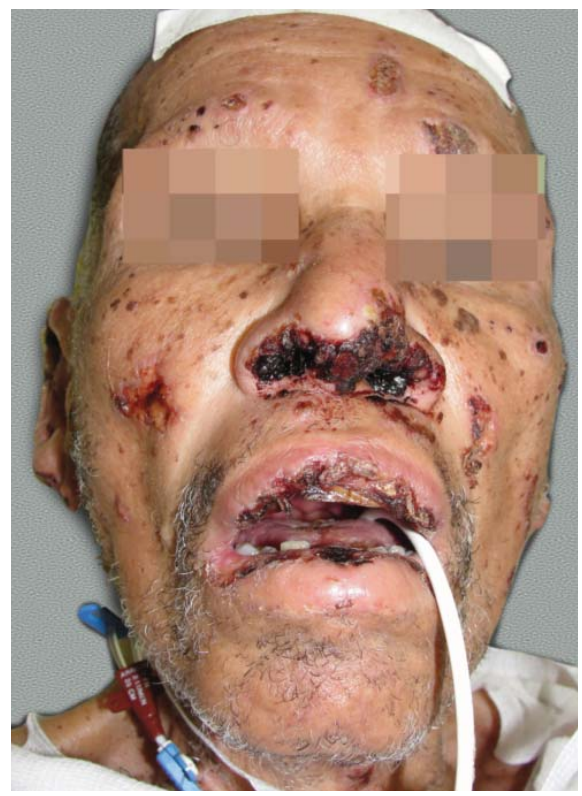

Figure 1: Crusted ulcerated lesions mainly in the oral and nasal cavities and presence of madarosis

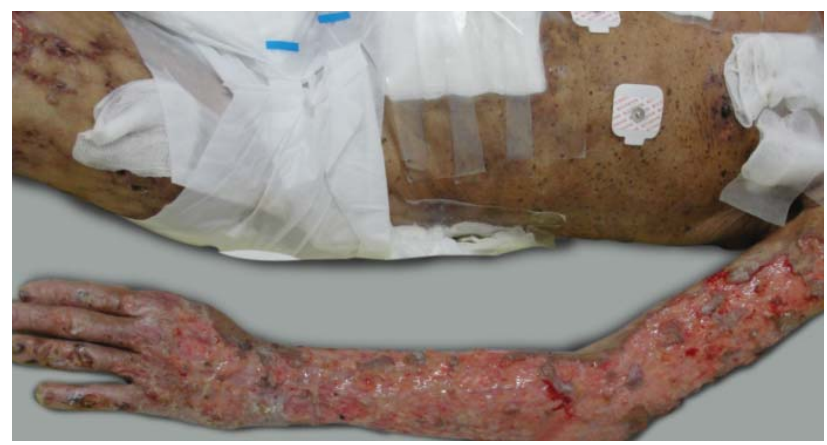

FIGURE 2: Converging of lesions, leaving large denuded areas

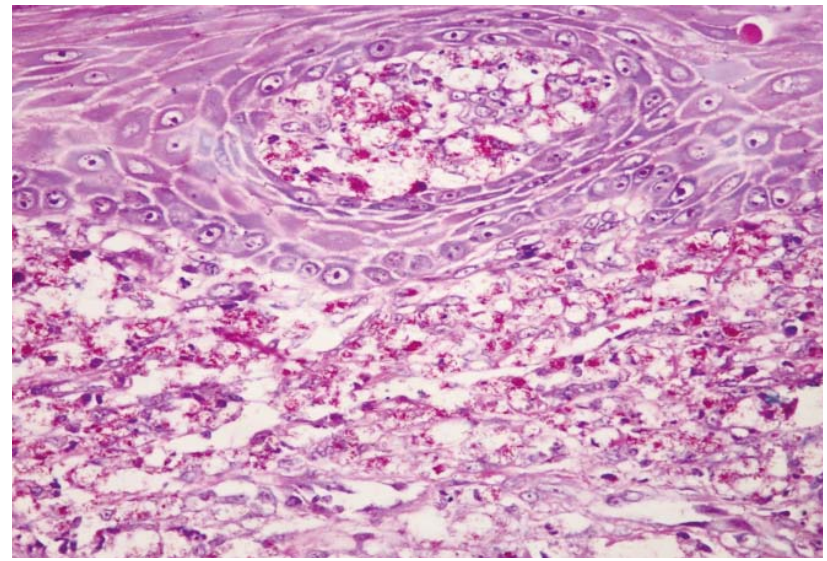

FIGURE 3: Presence of innumerous granular bacilli by the Fite-Faraco stain 


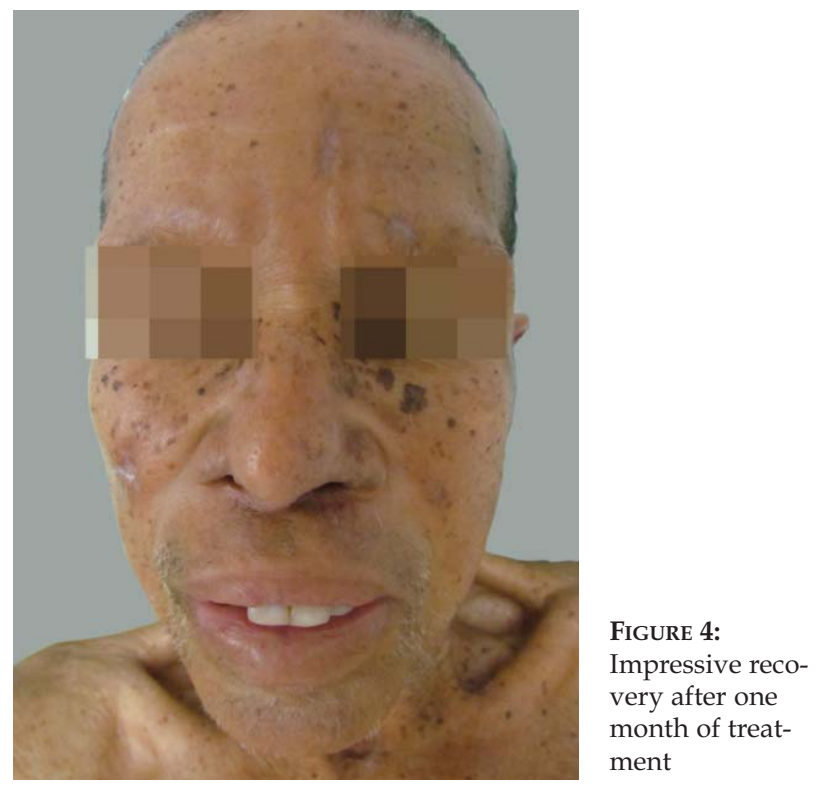

\section{DISCUSSION}

Lucio's phenomenon (FL) represents a severe cutaneous necrosis reaction that may occur in Lucio's leprosy and also in other forms of Virchowian hanseniasis. ${ }^{2}$ This is a rare syndrome, almost exclusively limited to patients with leprosy from Mexico and Central America, although it is rarely reported in Cuba, South America, United States, India, Polynesia, South Africa and Southeast Asia. FL occurs 3 to 4 years into the course of the disease and it is most common in patients that are either untreated or inadequately treated. ${ }^{3}$ This reaction is characterized by bouts of slightly infiltrated erythematous macules, which evolve with central necrosis and subsequent ulceration. These lesions affect mainly the extremities and usually regress in a period of two to four weeks, leaving atrophic star-like scars. ${ }^{4,5}$ The presence of dark, flaccid blisters may be observed. ${ }^{6}$ Many Virchowian hanseniasis' characteristics are often described, such as: thickening of the facial skin, alopecia in the eyebrows and eyelashes, paresthesia on the extremities and rhinitis. ${ }^{7}$ FL's pathophysiology is still unknown, however, it is a consensus that this is a thrombo-occlu- sive process. The main hypothesis is that bacterial liposaccharides would stimulate macrophages to release TNF and interleukin1 (IL-1). Those products would act on the endothelial cells facilitating the production of prostaglandins, interleukin-6 (IL-6) and coagulation factor III, thus causing the formation of thrombi inside the vessels and also promoting tissue necrosis on predisposed patients. ${ }^{6}$ Histologic examination demonstrates: a decrease in the vascular lumen due to endothelial cellular proliferation; capillary thrombosis on the superior and medium dermis resulting in an ulcerated epidermis; inflammatory infiltrate with foamy histiocytes and innumerous bacilli, even inside the vascular walls. ${ }^{8}$ There are few reports of leukocytoclastic vasculitis in early lesions. All these findings may be observed both in the clinically altered skin as well as in the apparently healthy one. Among several differential diagnosis, one must consider the erythema nodosum leprosum (a neutrophilic vasculitis, mediated by immunocomplexes, with variable involvement of the panniculus), easily distinguished by the presence of painful nodules that rarely ulcerate, small quantity of bacilli and general symptoms like fever, adenomegaly, apathy, possibly arthrites, neurites, iridocyclites and the fact that it affects more frequently those patients on the first six months of treatment. Multibacillary multidrug therapy (PQT-MB) is the treatment of choice for FL. What supports this theory is the massive replication of $\mathrm{M}$ leprae, a triggering event for FL that must be arrested in order to stop the leprosy reaction. The role of corticosteroids is still controversial. In the clinical case described above, we did not include corticoids due to the risk of severe infection. The progressive improvement of the patient, in a matter of few days, ratified our choice. Thalidomide and clofazimine are less effective to treat erythema nodosum leprosum (ENL). Prognosis is variable, and may result in death by sepsis or coagulation disorders. ${ }^{6}$ The authors discussed the case of a patient with exuberant FL manifestations, which presented an excellent response to treatment with only PQT-MB. 


\section{REFERENCES}

1. Saúde.gov.br [página da internet]. Brasil. Ministério da saúde. Secretaria de Políticas de Saúde. Departamento de Atenção Básica. Guia para o controle da Hanseníase. Brasília: Ministério da Saúde; 2002. [acesso 26 jul 2012]. Disponível em: http://bvsms.saude.gov.br/bvs/publicacoes/guia_de_hanseniase.pdf. Guideline for the control of Hanseniasis. Available in Portuguese at http://bvsms.saude.gov.br/bvs/publicacoes/guia_de_hanseniase.pdf.

2. Helmer KA, kucharski-Fleischfresser I, Esmanhoto LDK. The Lucio's phenomenon (necrotizing erythema) in pregnancy. An Bras Dermatol. 2004;79:205-10.

3. Kumari R, Thappa DM, Basu D. A fatal case of Lucio's phenomenon from India. Dermatol Online J. 2008;14:10.

4. Lucio R, Alvarado I. Opusculo Sobre el Mal de San Lazaro 0, Elefan ciasis de los Griegos. Mexico: M. Murguia y Cia; 1852. p.53.

5. Latapi F, Zamora AC. The "spotted" leprosy of Lucio (la lepra manchada de Lucio): An introduction to its clinical and histological study. Int J Lepr. 1948;16:421-30.

6. Azulay-Abulafia L, Spinelli L. Revendo a Hanseníase de Lucio e o Fenômeno de Lucio (Revisiting Lucio's leprosy and Lucio's phenomenon). Med Cutan Lat Am. 2004;33125-33.

7. NSC.gov.sg [homepage on the Internet]. Por A, Kwang TY, Swee SC. Lucio's Phenomenon: A rare necrotizing Type 2 reaction in lepromatous leprosy. Bulletin for medical practitioners. National Skin Centre Singapore; 1995. [cited 2012 Jul 26]. Available from: http://www.nsc.gov.sg/showpage.asp?id=328.

8. Vargas-Ocampo F. Diffuse leprosy of Lucio and Latapí: a histologic study. Lepr Rev. 2007;78:248-60.

\author{
MAILING ADDRESS: \\ Amanda Braga Peixoto \\ Rua Cesar Zama, 185 - Lins de Vasconcelos \\ 20725-090 - Rio de Janeiro - RJ \\ Brazil \\ E-mail: amandabrag@globo.com
}

How to cite this article: Peixoto AB, Portela PS, Leal FRPC, Brotas AM, Santos-Rodrigues NC. Lucio's Phenomenon. Case study of an exceptional response to treatment exclusively with multibacillary multidrug therapy. An Bras Dermatol. 2013;88(6 Suppl 1):S93-6. 